\title{
Pengolahan Kekayaan Sumber Daya Intelektual Menggunakan Teknologi Knowledge Management
}

\author{
(Processing of Intellectual Property Resources Using Knowledge Management) \\ Febrian Wahyu Christanto \\ Fakultas Teknologi Informasi dan Komunikasi \\ Universitas Semarang
}

\begin{abstract}
The most important asset in the modern management science is the human resource that can generate knowledge that can be used to maintain the stability of the company in case of regeneration of labor in a company. Problems arise because the majority of knowledge in a company is Tacit knowledge that stored in the brain workforce of experience gained during the work, while Explicit knowledge is only a fraction of the knowledge that can be poured into a medium. Knowledge is very important to use to achieve success and maintain the stability of the company. With the Knowledge Management technology, it is expected that the need for knowledge and Intellectual Property Resources of the operations of a company can be used safely, quickly, easily, and inexpensively.
\end{abstract}

Keywords : knowledge management, tacit knowledge, explicit knowledge

\section{PENDAHULUAN}

Dengan kemajuan jaman pada era modern seperti pada saat ini, pergeseran-pergeseran di seluruh bidang kehidupan manusia pun menjadi bergeser sedikit demi sedikit dari cara yang masih bersifat tradisional menjadi suatu bidang dengan sudut pandang yang lebih modern. Arus modernitas yang muncul, menuntut kecepatan dan kemudahan dalam penggunaannya. Saat ini hamper semua bidang menggunakan teknologi dan bantuan peralatan lain untuk memudahkan manusia dalam menjalani kehidupan. Dari sarana komunikasi, trasportasi, konsumsi, distribusi, dan sebagainya, semua membutuhkan kecepatan dan ketepatan sehingga peran teknologi sangat sentral pada era ini.

Sebagai contoh adalah ilmu tentang manajemen yang pada jaman dahulu dikenal dengan sebutan 5 M yaitu singkatan dari Man, Money, Method, Machine, dan Market untuk menggambarkan asset yang dimiliki sebuah perusahaan, sekarang bergeser lebih kepada hal-hal yang dapat dijadikan sebagai sumber ekonomi, yaitu
Money dan sumber daya alam. Tetapi pada era modern ini, asset terpenting dalam suatu perusahaan adalah Man atau dalam arti sumber daya manusia yang dapat menghasilkan suatu knowledge atau pengetahuan yang dapat digunakan untuk menyelesaikan suatu permasalahan perusahaan tersebut, sehingga stabilitas perusahaan dan kemajuan perusahaan tersebut dapat tetap bertumbuh dengan baik.

Dengan pengetahuan yang dikelola dengan baik, maka resiko untuk terjadi kegagalan dalam suatu perusahaan akan terminimalisasi dengan baik, karena perusahaan tersebut sudah memiliki kumpulan pengetahuan yang dapat digunakan untuk menyelesaikan suatu masalah. Pengetahuan yang didapatkan perusahaan selama perusahaan itu berdiri ada baiknya untuk dikelola dan disimpan untuk proses ke depan apabila menghadapi suatu permasalahan yang sama lagi.

Permasalahan timbul disini, karena tentu saja biaya yang dikeluarkan tidak murah, tetapi sebenarnya keuntungan yang didapatkan lebih mahal daripada biaya untuk membangun infrastruktur untuk mengelola pengetahuan. Terkadang dalam suatu perusahaan tidak mengelola pengetahuan dengan baik karena beberapa hal seperti ketidakmauan orang untuk berbagi informasi, ketidakdisiplinan anggota untuk menuliskan pengetahuan yang didapat karena berbagai macam alasan, serta budaya negara ini yang cenderung suka terhadap hal yang lisan, sehingga proses mengelola pengetahuan terhambat.

Permasalahan yang timbul membuat proses transfer pengetahuan antar sesama anggota perusahaan tidak terjadi. Anggota yang hebat dan mempunyai banyak pengetahuan akan semakin hebat, dan anggota baru akan tetap kurang pengalaman dan pengetahuan. Ini sangat berbahaya bagi stabilitas perusahaan karena apabila anggota yang mempunyai banyak pengetahuan dan pengalaman harus keluar dari perusahaan, sehingga knowledge yang selama ini digunakan untuk 
mendukung stabilitas perusahaan akan sirna dengan sia-sia. Sebuah riset yang dilakukan oleh Delphi Group menyimpulkan bahwa pengetahuan yang tersimpan dalam suatu perusahaan dibagi menjadi beberapa struktur, yaitu dipikiran (otak) karyawan sejumlah $42 \%$, dokumen kertas sejumlah $26 \%$, dokumen elektronik sejumlah $20 \%$, dan Knowledge base elektronik sejumlah $12 \%$ [1].

Dari beberapa pemahaman inilah dirasa sangat penting bahwa sebuah perusahaan mengelola basis pengetahuan atau sumber pengetahuannya melalui suatu media yang aman, cepat, mudah, dan murah. Knowledge ini nantinya dapat dipakai tenaga kerja perusahaan untuk menyelesaikan pekerjaannya sehingga tercipta stabilitas perusahaan yang baik.

\section{INFORMASI, PENGETAHUAN, DAN MANAJEMEN}

Sebelum memasuki pemahaman tentang konsep dasar dan implementasinya ada baiknya untuk membahas terlebih dahulu arti dari informasi, pengetahuan, serta manajemen sebagai kata dasar yang penting dalam pembentukan knowledge management. Dimulai dari konsep pemahaman akan fakta yang merupakan kumpulan objek yang nyata berkembang dari kumpulan fakta tersebut menjadi sebuah data. Kumpulan data inilah yang akan disebut informasi yang kemudian akan dikumpulkan menjadi sebuah pengetahuan atau knowledge.

Informasi adalah sebuah pengetahuan yang disajikan kepada seseorang dalam bentuk yang dapat dipahami. Informasi disini dapat berupa hal yang lisan maupun tertulis yang dapat dimengerti oleh orang yang mendapatkannya. Informasi dapat berarti pula sebagai data yang telah diproses atau ditata untuk menyajikan suatu fakta yang mengandung arti.

Sedangkan knowledge atau pengetahuan yang merupakan kumpulan dari beberapa informasi relevan yang diolah untuk dapat diserap dan dipadukan dengan dan dalam pemikiran seseorang. Dari pengetahuan inilah seorang manusia sebagai individu maupun sebagai perusahaan dapat menjalani bidang kehidupannya dengan baik. Dengan pengetahuan seorang manusia ataupun sebuah perusahaan dapat belajar untuk mengatasi masalah yang lama maupun mengembangkannya untuk menyelesaikan masalah yang baru sehingga meminimalisasikan resiko kegagalan.

Manajemen adalah istilah ekonomi dan organisasi yang merupakan proses perencanaan dan pengendalian kinerja atau pelaksanaan setiap jenis kegiatan. Setiap kegiatan yang bersifat individu maupun organisasi dalam melaksanakannya kegiatannya. Dengan konsep inilah knowledge management terbentuk dan menjadi esensi dan inti penting dari asset sebuah organisasi [2].

\section{KNOWLEDGE MANAGEMENT}

Pengertian para ahli mengenai knowledge management bervariasi karena luasnya cakupan yang ada dalam knowledge management. Knowledge management diartikan sebagai sebuah proses yang dapat membantu perusahaan dalam menemukan, memilih, menyebarkan, serta memindahkan informasi penting dan mahal yang biasanya digunakan dalam aktivitas menyelesaikan masalah, untuk pembelajaran, perencanaan strategi, dan pengambilan keputusan [3]. Knowledge Management dapat berarti pula sebagai sebuah proses untuk menciptakan, memvalidasi, mempresentasikan, mendistribusikan, serta mengaplikasikan [4]. Kreasi dari pengetahuan baru, sharing pengetahuan dan penyebarannya, serta alat dan metode untuk mempromosikannya dapat pula dianggap sebagai pengertian Knowledge Management menurut Maki [5]. Sedangkan menurut World IQ [6] Knowledge Management adalah penggabungan proses antara kreasi, penyebaran, pengujian, integrasi, dan pemanfaatan pengetahuan di dalam suatu perusahaan.

Dari beberapa pengertian yang diberikan oleh para ahli di bidang Knowledge Management, dapat disimpulkan bahwa Knowledge Management adalah suatu upaya dalam mendokumentasi dan mengelola segala jenis pengetahuan, pengalaman, maupun ilmu yang berguna bagi suatu perusahaan ataupun perusahaan dalam menyelesaikan suatu masalah untuk kemajuan perusahaan itu sendiri. Knowledge Management harus dibuat dalam bentuk sistem untuk memudahkan setiap anggota yang ada dalam perusahaan dalam proses sharing informasi maupun regenerasi perusahaan, agar waktu untuk menyelesaikan pekerjaan tetap stabil walaupun orang yang ada di dalamnya berubah dan ciri khas suatu perusahaan tetap berdiri dengan stabil.

Permasalahan akan muncul disini karena beberapa budaya yang ada untuk proses Knowledge Management berjalan dengan baik. Yang pertama adalah ketidakmauan orang atau anggota perusahaan untuk berbagi informasi dengan anggota lain. Ini menyebabkan anggota yang lama dan mempunyai pengetahuan banyak akan berkembang menjadi lebih hebat, sedangkan anggota baru akan membutuhkan waktu yang sangat lama untuk beradaptasi dengan metode kerja perusahaan. Permasalahan kedua yang muncul adalah masalah ketidakdisiplinan anggota untuk menuliskan pengetahuan yang didapat, karena kebanyakan dari anggota mendapatkan pengetahuan tersebut dari pengalaman, sehingga pengetahuan tersebut hanya tersimpan di dalam pikiran anggota 
dan sangat sulit untuk menumpahkannya di dalam suatu media karena ketidakbiasaan anggota untuk menulis. Budaya lain yang cenderung menghambat adalah budaya untuk cenderung berbicara secara lisan karena dianggap lebih sopan. Budaya ini sebenarnya baik di dalam kehidupan bermasyarakat, tetapi tidak dalam budaya hidup suatu perusahaan. Suatu perusahaan membutuhkan suatu dokumen sebagai arsip pengetahuan untuk kestabilan perusahaan, apabila budaya yang selalu cenderung lisan, maka pengetahuan hanya diketahui oleh beberapa orang saja di dalam suatu perusahaan, sehingga pengetahuan yang didapatkan oleh seluruh anggota tidak merata dapat diserap, ini akan berimbas pada waktu yang dibutuhkan untuk menyelesaikan suatu pekerjaan yang lebih lama dari target yang sudah ditentukan.

Tujuan yang ingin diharapkan dalam pembuatan sistem Knowledge Management disini sebenarnya adalah untuk penggunaan kembali pengetahuan yang sudah ada untuk menyelesaikan permaasalahan perusahaan ataupun sebagai patokan untuk menciptakan inovasi yang baru kembali. Tentu saja dengan hal ini akan mempercepat perusahaan terutama bagi seluruh anggota yang berada di dalamnya untuk mempercepat fungsi penciptaan pengetahuan yang baru lagi dari pengetahuan lama yang sudah ada. Tujuan lain yang diharapkan dari sistem ini adalah untuk mengetahui pula kekuatan sumber daya manusia yang dimiliki oleh perusahaan sudah sesuai dengan kebutuhan atau belum, apabila belum maka akan dilakukan rekruitmen anggota baru lagi dengan kemampuan dan pengetahuan yang sudah ditentukan untuk memenuhi kebutuhan perusahaan. Hal-hal tersebut tentunya dilakukan dan diharapkan untuk menjaga suatu pergerakan perusahaan agar tetap stabil berdiri, beroperasi, maupun berproduksi meskipun arus keluar dan masuk sumber daya manusia selalu terjadi dalam perusahaan.

Disimpulkan dari beberapa pertimbangan yang sudah terjabar, maka jenis Knowledge dapat dibedakan menjadi dua yaitu "Explicit Knowledge" dan "Tacit Knowledge". Kedua hal ini berlawanan dalam hal pendokumentasian pengetahuan. Explicit Knowledge adalah pengetahuan yang tertulis, terarsip, dan tersebar melalaui berbagai media yang dapat digunakan untuk media pembelajaran orang lain. Sedangkan Tacit Knowledge adalah pengetahuan yang didapat dari pengalaman atau hasil pemikiran seseorang yang belum ditransformasikan melalui media. Dalam hal ini Tacit Knowledge menggambarkan bahwa pengetahuan ini masih terdapat dalam pikiran seseorang dan orang itulah yang hanya tahu karena pengetahuan tersebut belum ditrasformasikan ke dalam media. Tujuan dari
Knowledge Management adalah tentu saja mendokumentasikan baik Explicit Knowledge maupun Tacit Knowledge ke dalam suatu media yang mudah diakses dan dipelajari orang lain, atau mudah dipelajari oleh anggota lain di dalam suatu perusahaan.

Dalam Knowledge Management terdapat beberapa komponen pembentuk agar Knowledge Management dapat berjalan dengan baik yang menurut Gauthama [7] antara lain adalah perangkat manusia (SDM) yang merupakan komponen terpenting dari sistem ini karena pengetahuan yang akan dikelola adalah dari hasil pemikiran, pengalaman, dan pengetahuan dari manusia. Perangkat teknis seperti mesin dan peralatan adalah media eksekusi setelah pengetahuan disimpan, Knowledge Management berbentuk sistem dan diperlukan suatu mesin atau peralatan untuk realisasi dari knowledge tersebut. Komponen lain yang mendukung Knowledge Management adalah perangkat perusahaan yang sangat jelas dibutuhkan untuk membentuk Knowledge Management karena akan dibagi anggota mana saja yang berhak memasukkan pengetahuan di dalam sistem ini, anggota mana saja yang berhak mengakses sistem ini, dan anggota mana saja yang tidak berhak mengakses sistem ini. Komponen terakhir untuk mendukung Knowledge Management System yang efektif dan efisien maka dibutuhkan perangkat teknologi yang mendukung terwujudnya sistem ini. Perangkat teknologi dalam hal ini penting pula agar pengatahuan yang nantinya disimpan dapat tersimpan dengan baik dan dapat diolah untuk mempermudah proses pembelajaran atau sharing informasi antar anggota dalam suatu perusahaan. Knowledge Management juga dapat digambarkan di dalam suatu siklus perjalanan Knowlegde yang terdapat dalam Gambar 1.

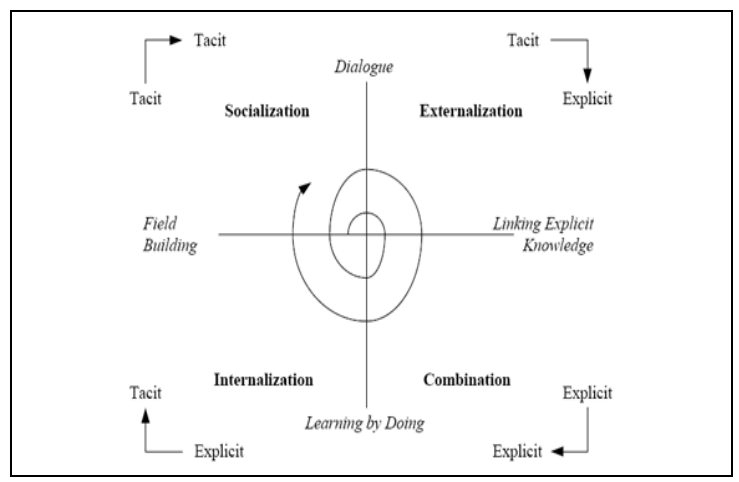

Gambar 1 Siklus Perjalanan Knowledge [8]

Dalam Gambar 1 dijelaskan siklus perjalanan pengetahuan menurut Ikujiro Nonaka 
yang digambarkan dengan suatu spiral untuk menggambarakan lebih jelas. Dalam siklus ini terdapat empat tahapan penyampaian pengetahuan, yaitu Socialization, Externalization, Combination, dan Internalization. Keempat proses ini diawali dengan proses Socialization yaitu suatu pondasi dari siklus pengetahuan yang merupakan transformasi pengetahuan dari orang ke orang secara lisan sehingga dapat disebut proses dari Tacit Knowledge ke Tacit Knowledge kembali. Proses kedua adalah Externalization yaitu Tacit Knowledge yang tersimpan di dalam pikiran manusia, mulai ditumpahkan ke dalam beberapa media untuk membentuk suatu Explicit Knowledge. Proses ketiga dari siklus ini adalah Combination yang merupakan gambaran dari Explicit Knowledge yang digunakan untuk menciptakan Explicit Knowledge yang baru melalui proses inovasi maupun modifikasi pengetahuan. Menginjak ke tahapan berikutnya maka anggota perusahaan sudah bisa mempelajari pengetahuan yang sudah ada untuk diimplementasikan ke dalam pekerjaan nyata melalui proses Internalization yaitu proses pengubahan Explicit Knowledge menjadi Tacit Knowledge kembali. Dari siklus ini keempat elemen dan tahapan siklus akan selalu berputar dan berelasi.

Tahapan pembentukan Knowledge Management lainnya adalah menurut Davenport, dkk [9] yaitu suatu proses kegiatan yang meliputi menciptakan pengetahuan, menangkap pengetahuan, menyaring pengethauan, menyimpan pengetahuan, mengelola pengetahuan, menyebarkan pengetahuan, serta menciptakan pengetahuan baru dari pengetahuan lama. Tahapan-tahapan ini membuktikan bahwa dibutuhkan waktu untuk membentuk Knowledge Management System yang efektif dan efisien untuk kebutuhan perusahaan.

\section{PEMANFAATAN TEKNOLOGI UNTUK KNOWLEDGE MANAGEMENT}

Knowledge Management saat ini akan lebih padu dan aman apabila didukung oleh teknologi yang ada dan berkembang saat ini. Tentu tujuan itu bukanlah suatu pemborosan tetapi suatu investasi masa depan agar pengetahuan yang didapat tidak hilang secara sia-sia. Sistem pakar adalah suatu implementasi yang umum untuk fungsi Knowledge Management. Sistem pakar dapat digambarkan sebagai suatu program komputer yang mengandung pengetahuan dari satu atau lebih dari satu tentang kepakaran ahli mengenai suatu bidang yang spesifik. Dengan sistem kepakaran ini, pengetahuan anggota dalam suatu perusahaan dapat dipakai untuk menyelesaikan masalah yang dialami perusahaan nantinya. Bentuk sistem pakar adalah suatu program yang dibuat berdasarkan suatu set aturan yang menganalisa informasi mengenai suatu kelas masalah spesifik serta analisis matematis dari masalah tersebut.

Sistem pakar merupakan salah satu teknologi andalan dalam Knowledge Management melalui empat skema penerapan [10] yaitu . CaseBased Reasoning (CBR) yang merupakan representasi pengetahuan berdasarkan pengalaman termasuk kasus dan solusinya. Dalam CBR, pengetahuan yang timbul karena pengalaman anggota perusahaan maupun pakar akan disimpan dalam Knowledge Management System. Ini berarti adalah proses mengubah Tacit Knowledge menjadi sebuah Explicit Knowledge. Rule-Based Reasoning $(R B R)$ mengandalkan serangkaian aturan-aturan yang merupakan representasi dari pengetahuan dan pengalaman karyawan dalam memecahkan kasus yang rumit. Dalam hal ini terdapat tahapan-tahapan yang pernah dilalui untuk menyelesaikan suatu masalah. Tahapan inilah yang disimpan pula di dalam Knowledge Management System. Sedangkan Model-Based Reasoning (MBR) digunakan melalui representasi pengetahuan dalam bentuk atribut, perilaku antar hubungan, maupun simulasi proses terbentuknya pengetahuan. Jadi dalam Knowledge Management System, untuk membentuk suatu knowledge yang akan digunakan untuk mengakomodasi masalah dapat dimodelkan terlebih dahulu sehingga mempermudah penalaran dalam menyelesaikan suatu permasalahan. Skema penerapan terakhir dari Knowledge Management adalah Constrain-Satisfaction Reasoning (RBR dan $M B R$ ) yang merupakan perpaduan antara Rule-Based Reasoning dan Model-Based Reasoning dalam membentuk suatu knowledge. CSR biasanya akan menghasilkan suatu knowledge yang baru dari knowledge yang sudah ada sebelumnya.

Dari gambaran tentang sistem pakar ini dapat dikemukakan bahwa sistem pakar mengadopsi kemampuan, pengetahuan, dan pengalaman seseorang untuk menyelesaikan suatu masalah. Tujuan pengadopsian ini adalah kemudahan akses, kecepatan, dan faktor biaya karena kepakaran seseorang akan disimpan ke dalam sistem ini, sehingga kepakaran ini akan tetap stabil walaupun umur dan waktu telah berubah.

Knowledge Management System mendukung pula proses peningkatan kompetensi dari setiap anggota yang terlibat dalam jaringan pengetahuan dalam suatu perusahaan. Dalam hal ini secara garis besar dapat dibagi modul Knowledge Management System adalah meliputi direktori pengetahuan dan transfer pengetahuan. Segala Knowledge yang telah dicurahkan di dalam media akan disimpan ke dalam direktori pengetahuan untuk keamanan data dan arsipnya, sedangkan saat anggota 
mengakses sistem ini untuk mencari suatu usulan atau jawaban tentang permasalahan yang sedang dihadapi, maka disitulah akan terjadi transfer pengetahuan sehingga menambah kepakaran anggota itu sendiri untuk bekerja lebih baik lagi [11]. Selain sistem pakar banyak sekali aplikasi berbasis Website sekarang ini yang menggunakan konsep Knowledge Management yang antara lain terdapat di Gambar 2 berikut.

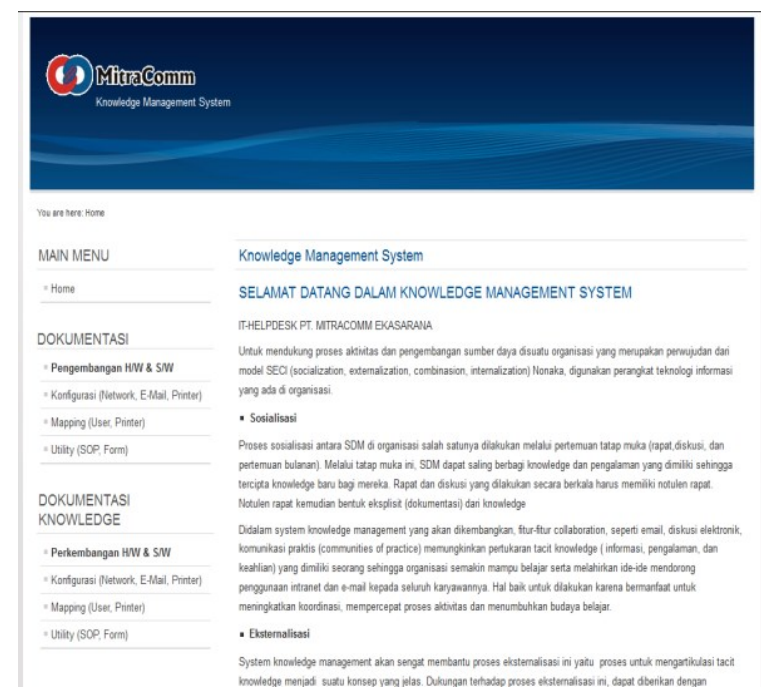

Gambar 2 Aplikasi Knowledge Management Koperasi

Gambar 2 adalah suatu aplikasi Knowledge Management yang dipadukan dengan teknologi. Mitra Comm adalah Website untuk koperasi yang menyediakan Knowledge Management System untuk para pegawainya. Saat ini memang banyak sekali Knowledge Management System yang digunakan untuk mempermudah pekerjaan suatu perusahaan baik seperti Unit Kegiatan Masyarakat (UKM) sampai ke tingkat level korporat. Untuk Knowledge Management di bidang keilmuwan terdapat dalam Gambar 3.

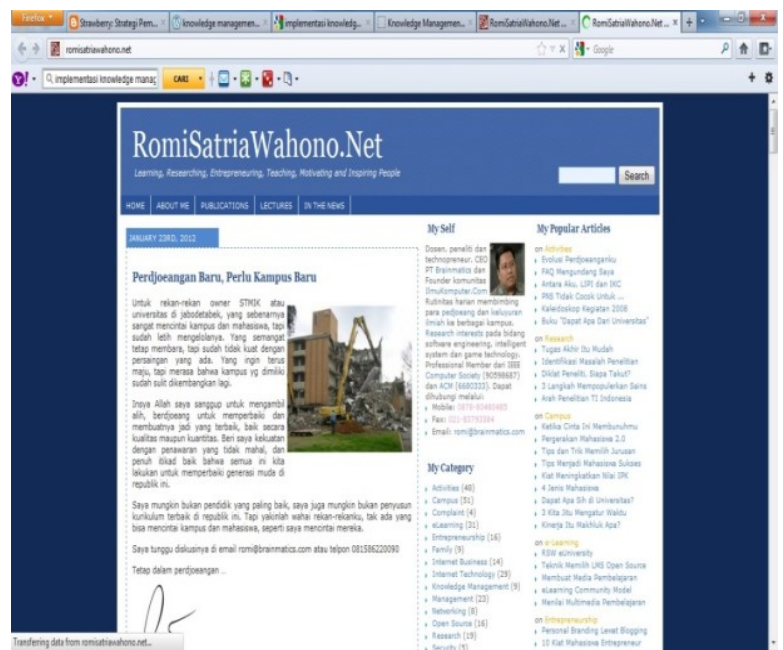

Gambar 3 Aplikasi Knowledge Management Keilmuwan

Gambar 3 menggambarkan suatu Knowledge Management System berbasis Website di bidang keilmuwan. Dalam aplikasi ini semua artikel, modul, maupun pengetahuan terutama di bidang teknologi disediakan dan dapat diunduh setiap waktu dan secara gratis dengan menggunakan internet.

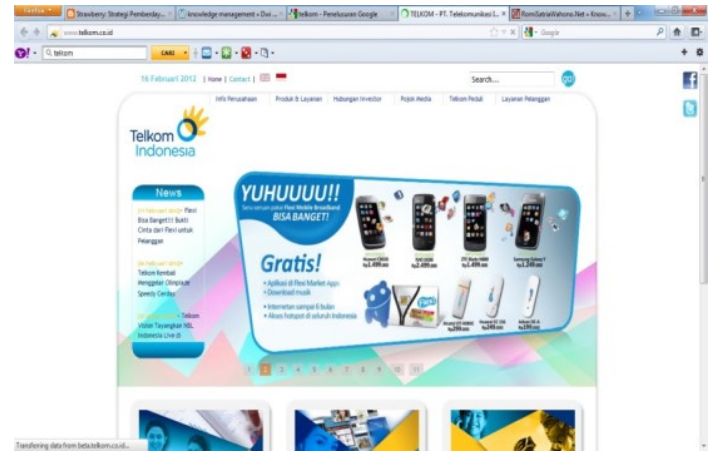

Gambar 4 Aplikasi Knowledge Management Bisnis Komunikasi

Dunia bisnis adalah sasaran utama dalam penggunaan Knowledge Management karena dasarnya suatu Knowledge Management memang kebanyakan digunakan dalam dunia bisnis. Dari aplikasi ini terdapat banyak sekali tutorial tentang teknologi terutama yang menyangkut tentang komunikasi dan perangkatnya yang dipakai oleh Telkom Indonesia. Aplikasi ini terdapat di dalam Gambar 4. Sedang cabang BUMN lain seperti Pertamina menggunakan aplikasi Knowledge Management bernama Komet. 




Gambar 5 Aplikasi Framework Pembuat Knowledge Management

Dari Gambar 5 adalah salah satu aplikasi yang berbasis Website pula yang digunakan untuk framework dalam pengembangan aplikasi Knowledge Management System. Aplikasi ini adalah berbayar, sehingga pelanggan tinggal berlangganan dan mengubah konten yang sesuai dengan kebutuhan untuk jalannya sistem di dalam perusahaan sendiri. Sedangkan aplikasi Knowledge Management yang menyediakan pengetahuan di bidang umum terdapat di dalam Gambar 6.

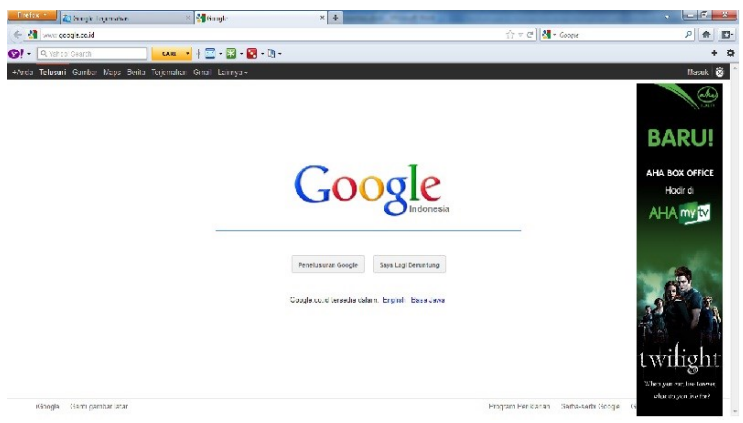

Gambar 6 Aplikasi Knowledge Management untuk Umum

Dalam Gambar 6 digambarkan yaitu salah satu aplikasi Knowledge Management System yang paling besar di dunia. Bersifat gratis dan dapat diunduh kapan saja lewat internet. Aplikasi ini menggunakan search engine dengan algoritma rating serta sistem pengusulan yang sangat memudahkan seseorang dalam mencari pengetahuan yang diinginkan dengan cepat dan efisien.

Untuk aplikasi Dekstop seperti sistem pakar jembatan timbang truk merupakan salah satu Knowledge Management pula yang digunakan oleh pemerintah dalam hal kontrol muatan truk sehingga akan menghemat jangka waktu aspal jalan karena muatan yang melewati tidak melebihi muatan. Aplikasi ini terdapat di dalam Gambar 7.

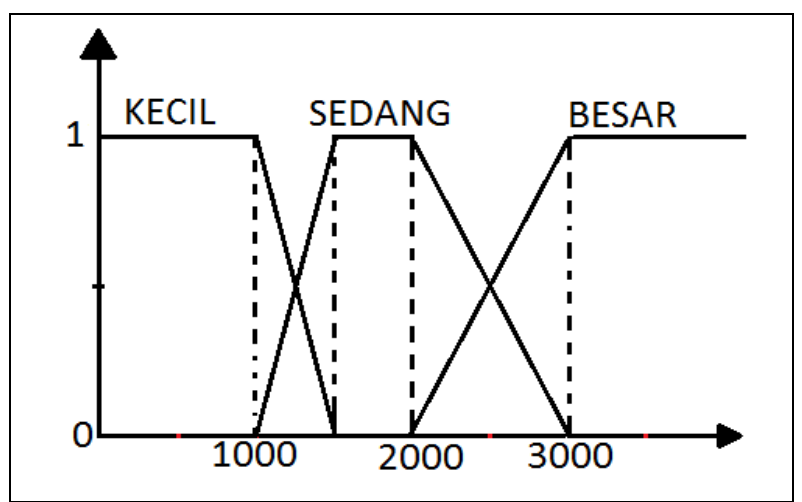

Gambar 7 Aplikasi Knowledge Management untuk Sistem Jembatan Timbang

\section{KESIMPULAN}

Dari beberapa analisa, pengamatan, dan pembelajaran ini dapat ditarik kesimpulan bahwa di era teknologi ini informasi yang membentuk suatu pengetahuan adalah suatu kunci untuk memperoleh keuntungan maupun kejayaan. Sehingga perlu pengelolaan yang teliti dan detail tentang pengetahuan kekayaan intelektual ini, Knowledge Management berperan penting dalam proses ini karena pengelolaan pengetahuan dan kekayaan intelektual akan terarsip di dalam sistem sehingga dapat dipergunakan perusahaan dalam operasinya hari demi hari agar tetap stabil atau bahkan lebih maju dari waktu ini. Dipadu dengan teknologi yang akan membentuk Knowledge Management System, akan menjadikan aset penting perusahaan yang berupa pengetahuan dari anggota perusahaan akan dapat diakses dengan cepat, mudah, dan murah.

Pada hakekatnya semua permasalahan dan persoalan akan dapat dihadapi apabila terdapat pengetahuan dan kekayaan intelektual yang mencukupi tentang permasalahan tersebut karena terdapat kemungkinan untuk permasalahan itu dihadapi berulang kali selama perusahaan berdiri, sehingga perusahaan dapat menyelesaikannya dengan baik atau cepat dengan pengetahuan dan kekayaan intelektual yang sudah dikelola sebelumnya di dalam sistem seperti sistem pakar. Kemungkinan terbentuk pengetahuan dan kekayaan intelektual baru disini sangat besar karena dalam penyelesaian suatu persoalan dibutuhkan pula suatu metode dan terobosan untuk mengakomodasi persoalan tersebut dengan baik agar tidak terulang lagi ke depan. Akan lebih baik lagi apabila anggota perusahaan tersebut sebelum keluar dari perusahaan diwajibkan untuk membuat terlebih dahulu pengetahuan, kekayaan intelektual, dan pengalaman yang dimiliki anggota tersebut selama bekerja dalam perusahaan untuk kemudian akan disimpan di dalam Knowledge Management System sehingga proses 
sharing informasi dan regenerasi perusahaan akan tetap berjalan dengan baik.

\section{DAFTAR PUSTAKA}

[1] Delphi Consulting Goup. 1997. Delphi on Knowledge Management, Research, and Perspective on Today's

Knowledge Lanscape. The Delphi Group.

[2] Haris, \& Jonathan Sofian Lusa. 2011. Model Knowledge Management System dengan Teknologi Cloud Computing. Jakarta : Fakultas Ilmu Komputer Universitas Budi Luhur.

[3] Gupta, A. K., \& Govindarajan, V. 2000. Knowledge

Flows Within Multinational Corporations. Strategic

Management Journal. (21:4) pp. 473-496.

[4] Bhatt, Diliip. 2000. Exellence Model and Management

Knowledge Implication.

www.knowledgemanagementcentre.com

(diakses

tanggal 23 Januari 2015).

[5] Maki, Tatsu. (2001). How to Draw and Create Manga.

Jakarta: Kepustakaan Populer Gramedia.

[6] IQ, World. 2007. Knowledge Management. www.worldiq.com (diakses tanggal 24 Januari 2015).

[7] Gauthama, Margaret P. 1999. Tiga Pilar Pengembangan Wilayah Sumber Alam, Sumber Daya Manusia. Jakarta.

[8] Nonaka, Ikujiro. 1991. The Knowledge Creating Company. New York: Oxford University.

[9] Davenport, Thomas H., \& Laurence Prusak. 1998.

Working Knoledge :How to

Organizations Manage What They Know.

Boston :

Harvard Business School Press.

[10] Wikipedia. 2011. Sistem Pakar. id.wikipedia.org (diakses tanggal 25 Januari 2015).
[11] Wahono, Romi Satria. 2008. Knowledge Management

dan Kiat Praktisnya.

www.romisatriawahono.net

(diakses tanggal 25 Januari 2015). 